\title{
FORMULASI MASKER GEL PEEL-OFF PERASAN LIDAH BUAYA (Aloe vera L.) DENGAN GELLING AGENT POLIVINIL ALKOHOL
}

\author{
Ivan Santoso ${ }^{1}$, Tria Prayoga ${ }^{2,}$, Ika Agustina $^{3}$, Wiwit Setya Rahayu ${ }^{4}$ \\ ${ }^{1,2,3,4}$ Akademi Farmasi IKIFA \\ Email Korespondensi : ivan apt@yahoo.co.id
}

\begin{abstract}
ABSTRAK
Lidah buaya (Aloe Vera L.) adalah tanaman yang biasa digunakan masyarakat lokal sebagai pelembab. Penggunaan lidah buaya dapat diaplikasikan dalam bentuk masker gel yang dikupas dengan polivinil alkohol sebagai agen pembentuk gel. Tujuan dari penelitian ini adalah untuk mengetahui pengaruh peningkatan alkohol polivinil sebagai agen pembentuk gel terhadap formulasi masker yang dikupas dari jus lidah buaya. Formulasi dibuat dalam beberapa konsentrasi, 10\%, 12\%, dan 14\% dengan menambahkan $0,5 \%$ jus lidah buaya. Setelah itu, formulasi dievaluasi selama 4 minggu tentang organoleptik, homogenitas, $\mathrm{pH}$, waktu pengeringan dan viskositas. Tanggal uji $\mathrm{pH}$ dan waktu pengeringan dianalisis dengan menggunakan ANOVA satu arah secara statistik dan kemudian dilanjutkan dengan uji Tukey HSD dan viskositas dianalisis dengan menggunakan Kruskall Wallis secara statistik yang menghasilkan signifikansi kurang dari 0,05 yang berarti ada perbedaan waktu pengeringan dan viskositas, di sisi lain tidak ada perbedaan dalam $\mathrm{pH}$.
\end{abstract}

Kata kunci: masker gel terkelupas, jus lidah buaya, alkohol polivinil 


\title{
FORMULATION OF PEEL-OFF GEL MASK FRUIT OF (Aloe vera L). WITH GELLING ALCOHOL POLYCLINYL AGENT
}

\begin{abstract}
Aloe vera (Aloe Vera L.) is a plant which commonly used by local people as moisturizer. The usage of aloe vera can be applied in form of peeled off gel mask with polyvinyl alcohol as gelling agent. The goal of this research is to determine the influence of increase of polyvinyl alcohol as gelling agent to the formulation of peeled off mask from aloe vera juice. The formulation was made in a few concentration, $10 \%, 12 \%$, and $14 \%$ by adding 0,5\% of aloe vera juice. After that, the formulation evaluated for 4 weeks about the organoleptics, homogenity, $\mathrm{pH}$, drying time and viscosity. The date of $\mathrm{pH}$ test and drying time analyzed by using one way ANOVA statistically and then followed by Tukey HSD test and the viscosity analyzed by using Kruskall Wallis statistically which result in the significantcy less than 0,05 that mean there are difference in drying time and viscosity, on the other hand there is no difference in $\mathrm{pH}$.
\end{abstract}

Keywords : peeled off gel mask, aloe vera juice, polyvinyl alcohol

\section{PENDAHULUAN}

Kulit merupakan organ terluas penyusun tubuh manusia yang terletak paling luar dan menutupi seluruh permukaan tubuh.Letak paling luar menyebabkan kulit pertama kali menerima rangsangan seperti rasa sakit,rangsangan sentuhan maupun pengaruh buruk dari luar (Wasitaatmadja, 1997). Kulit sangat mendukung penampilan seseorang, untuk itu perlu dirawat, dipelihara, dan dijaga kesehatannya.Kebanyakan masyarakat menggunakan berbagai macam sediaan kosmetik guna merawat kulit wajah.

Tujuan utama penggunaan kosmetik wajah adalah untuk pemeliharaan, menambah kepercayaan diri, menambah ketenangan, melindungi kulit dari kerusakan sinar ultra violet, polusi udara, faktor-faktor lingkungan lain, dan mencegah penuaan (Maysuhara, 2009). Salah satu zat yang dapat digunakan dalam perawatan kulit wajah adalah pelembab. Pelembab merupakan produk topikal yang digunakan untuk membuat kulit halus dan lembut pada lapisan luar kulit (epidermis) dengan meningkatkan hidrasi air (kandungan air) dalam kulit (Minarsih, 2006). Salah satu tanaman yang bermanfaat sebagai pelembab adalah lidah buaya (Aloe vera $\mathrm{L}$.)

Lidah buaya (Aloe vera L.) merupakan tanaman yang telah digunakan secara luas oleh masyarakat untuk bahan baku kosmetik. Selain harganya relatif murah, lidah buaya juga mudah diperoleh. Kandungan lignin mampu menembus dan meresap ke dalam kulit dan dapat membuat pertahanan hilangnya cairan tubuh dari permukaan kulit, sehingga kulit tidak cepat kering dan tetap terjaga kelembabannya (Minarsih, 2006). Salah satu cara untuk memperoleh manfaat dari lidah buaya adalah dengan cara pemerasan. Penggunaan lidah buaya untuk kesehatan kulit dapat dilakukan dengan pembuatan masker gel peeloffdari sari lidah buaya. 
Masker gel peel-off merupakan sediaan kosmetika perawatan kulit yang berbentuk gel dan setelah diaplikasikan ke kulit dalam waktu tertentu hingga mengering, sediaan ini akan membentuk lapisan film transparan yang elastis, sehingga dapat dikelupas (Yulin, 2015). Masker gel peel-off memiliki banyak keunggulan dibandingkan dengan masker jenis lain yaitu sediaan berbentuk gel yang sejuk, mampu merelaksasikan dan membersihkan wajah secara maksimal dengan mudah, daya lekat tinggi yang tidak menyumbat pori sehingga pernafasan pori tidak terganggu, mudah dikelupas dan dicuci dengan air. Suatu masker gel peel-off yang khas umumnya mengandung bahan aktif, gelling agent, penahan lembab, pengawet dan air (Goeswin, 2012). Pemilihan gelling agent adalah salah satu hal yang harus diperhatikan dalam membuat formulasi gel. Salah satu bahan yang dapat digunakan sebagai gelling agent adalah polivinil alkohol (PVA).

Polivinil alkohol (PVA) dapat menghasilkan gel yang cepat mengering dan membentuk lapisan film yang kuat dan plastis, memberikan kontak yang baik antara kulit dengan zat aktif serta peningkatan suhu dan sirkulasi darah pada kulit.Konsentrasi PVA yang dapat digunakan sebagai pembentuk lapisan film yaitu sebesar 10-16\% (Devy, Pangestuti, Nabilla, Lestari, \& R., 2016)

Berdasarkan paparan diatas, dilakukan pembuatan 3 formula masker gel peel-off perasan lidah buaya (Aloe vera L.) dengan kadargelling agent PVA yang berbeda untukmenghasilkansediaan masker gelpeel-offyang paling baik dan memenuhi persyaratan.

\section{METODE PENELITIAN}

Pembuatan perasan lidah buaya (Apgar, 2010)

Lidah buaya sebanyak $2 \mathrm{~kg}$ dibersihkan dari kotoran yang melekat, dan dicuci dengan air yang mengalir, kemudian permukaan daun dikeringkan.Bagian sisi daun yang berduri dibuang dan pangkal daun dipotong sekitar $1 \mathrm{~cm}$, kemudian dikuliti hingga melampaui bagian sel parenkim luar.Daging (gel) lidah buaya kemudian diperas dengan kain flanel.

\section{Uji identifikasi lidah buaya}

a. Identifikasi saponin

Uji saponin dilakukan dengan metode Forth yaitu dengan cara memasukkan $2 \mathrm{ml}$ sampel ke dalam tabung reaksi kemudian ditambahkan $10 \mathrm{ml}$ air suling lalu dikocok selama 30 detik. Diamati perubahan yang terjadi. Apabila terbentuk busa yang mantap (tidak hilang selama 30 detik) maka identifikasi menunjukkan adanya saponin.

b. Identifikasi tanin

Sebanyak $5 \mathrm{ml}$ lidah buaya dimasukkan kedalam tabung reaksi, lalu tambahkan 5 tetes $\mathrm{NaCl} 10 \%$ kemudian ditambahkan 3 tetes $\mathrm{FeCl}_{3}$, kemudian didiamkan beberapa saat. Apabila terbentuk warna hijau kehitaman maka menandakan adanya tanin

\section{Pembuatan masker gelpeel-off}

Timbang PVA, kemudian dikembangkan dengan menggunakan 
aquadest, untuk menambah kelarutan dapat di lakukan diatas hot platesuhu $80^{\circ} \mathrm{C}$, diaduk hingga mengembang sempurna dan terbentuk basis gel PVA yang homogen.Dalam wadah terpisah, HPMC dikembangkan menggunakan aquadest hingga mengembang dan terbentuk massa yang homogen. Setelah PVA dan HPMC mengembang sempurna, dimasukkan HPMC ke dalamnya PVA, lalu aduk sampai homogen.Larutkan metil paraben dan propil paraben ke dalam propilenglikol, aduk sampai homogen. Masukkan ke dalam PVA, aduk sampai homogenMasukkan perasan daun lidah buaya, aduk sampai homogen. Tambahkan dengan air suling ad 100 ml, aduk sampai homogen.Kemudian masukkan ke dalam wadah.

\section{Evaluasi sediaan masker gel peel-off}

Evaluasi sediaan masker dilakukan pada suhu kamar, kemudian diamati secara berkala pada minggu 0 , 1, 2, 3, dan 4 .

a. Uji organoleptis

Pengujian organoleptis dilakukan dengan melihat secara visual dan mengamati perubahanperubahan yang terjadi pada sediaan, yakni meliputipenampilan, bau dan warna.

b. Uji Homogenitas

Uji homogenitas dilakukan dengan cara sediaan diletakkan diatas kaca objek, lalu dilihat apakah ada partikel-partikel kasar atau ketidak homogenan. c. Viskositas

Uji ini meggunakan viskometer brookfield menggunakan spindle yang dipasang pada alat kemudian dicelupkan kedalam gel yang telah diletakkan dalam wadah. Atur kecepatan dan tunggu hasil skala hingga stabil.

\section{d. Pengukuran $\mathrm{pH}$}

Uji ini dapat dilakukan dengan menggunakan $\mathrm{pH}$ meter. Mula-mula elektroda dikalibrasikan dahulu dengan dapar standar $\mathrm{pH} 4$ dan $\mathrm{pH} 7$. Kemudian elektroda dicelupkan kedalam sediaan masker gel dan nilai $\mathrm{pH}$ kan muncul di layar. Masingmasing formula harus memenuhi rentang $\mathrm{pH}$ dengan kisaran sesuai dengan $\mathrm{pH}$ kulit yaitu 4,5-6,5

e. Waktu kering

Pengujian dilakukan dengan cara mengoleskan 1 gram dari masing masing formula sediaan ke punggung tangan dengan ukuran $7 \mathrm{~cm} \times 7 \mathrm{~cm}$ kemudian dilihat menggunakan stopwatch. Waktu yang diperlukan oleh sediaan untuk mengering, yaitu waktu hingga sediaan membentuk lapisan film.

\section{HASIL DAN PEMBAHASAN}

\section{Hasil Identifikasi Lidah Buaya (Aloe} Vera L.)

Hasil identifikasi pada perasan lidah buaya dapat dilihat pada tabel berikut. 
Tabel 1. Hasil Identifikasi

\begin{tabular}{|c|c|c|}
\hline No & Kandungan & Hasil \\
\hline 1. & Saponin & + \\
\hline 2. & Tanin & + \\
\hline
\end{tabular}

\section{Hasil evaluasi homogenitas dan organoleptis}

Uji Identifikasi hanya dilakukan pada saponin dan tannin karena metabolit sekunder ini diketahui memiliki aktivitas antiseptik (Purbaya, 2003).

Masker gel peel-off perasan lidah buaya dibuat dalam 3 formula dengan menggunakan kadar polivinil alkohol $10 \%$, 12\%, dan $14 \%$ sebagai gelling agent. Propilenglikol digunakan sebagai humektan yang akan menjaga kestabilan sediaan gel dengan cara mengabsorbsi lembab dari lingkungan dan mengurangi penguapan air dari sediaan. Penggunaan nipagin dan nipasol sebagai pengawet untuk menghindari pertumbuhan mikroba karena adanya kandungan air dalam jumlah besar dalam sediaan.Lidah buaya digunakan sebagai zat aktif yang berguna untuk melembabkan kulit. Evaluasi sediaan masker gel dilakukan pada suhu kamar selama 4 minggu waktu penelitian.
Hasil pemeriksaan organoleptis dan homgenitas dapat dilihat pada tabel 2 berikut.Secara organoleptis, keseluruhan sediaan masker peel-off pada awal berwarna putih susu, lalu perlahan setelah dilakukan pengujian terjadi perubahan warna menjadi jernih (tidak berwarna). Perubahan warna sediaan diakibatkan karena berkurangnya jumlah gelembung. Pada saat pengujian awal, terdapat banyak gelembung udara dan sediaan berwarna putih susu. Gelembung yang sangat banyak ini dimungkinkan karena proses pengadukan selama pembuatan sediaan yang dapat merangkap udara disekitar sediaan yang bergerak melingkar. Hal ini disebabkan karena seiring dengan lamanya penyimpanan, maka udara didalam gelembung yang membentuk buih menekan dinding gelembung dengan kuat sehingga gelembung tersebut pecah dan perlahan berkurang (Yulin, 2015). Ketiga formula sediaan tidak menunjukkan terjadinya perubahan homogenitas. Hal ini dapat menunjukkan bahwa bahan-bahan dalam gel dapat terlarut dan bercampur sempurna secara homogen.

Tabel 2. hasil pemeriksaan organoleptis dan homogenitas

\begin{tabular}{clll}
\hline Waktu & \multicolumn{1}{c}{ Formula 1 } & \multicolumn{1}{c}{ Formula 2 } & \multicolumn{1}{c}{ Formula 3 } \\
\hline Minggu 0 & $\begin{array}{l}\text { Cair,Putih susu, } \\
\text { berbau khas, } \\
\text { homogen, ada } \\
\text { gelembung udara }\end{array}$ & $\begin{array}{l}\text { Cair, Putih susu, } \\
\text { berbau khas, } \\
\text { homogen, ada } \\
\text { gelembung udara }\end{array}$ & $\begin{array}{l}\text { Cair, Putih susu, berbau } \\
\text { khas, homogen, ada } \\
\text { gelembung udara }\end{array}$ \\
\hline Minggu 1 & Cair, Bening, berbau & Cair, Bening, berbau & Cair, Bening, berbau \\
& khas, homogen, & khas, homogen, & khas, homogen, \\
& gelembung udara & gelembung udara & gelembung udara \\
berkurang dari & berkurang dari & berkurang dari \\
\hline
\end{tabular}




\begin{tabular}{llll}
\hline Minggu 2 & $\begin{array}{l}\text { Agak kental, Bening, } \\
\text { berbau khas, } \\
\text { homogen, tidak ada } \\
\text { gelembung udara }\end{array}$ & $\begin{array}{c}\text { Agak kental, Bening, } \\
\text { berbau khas, } \\
\text { homogen, tidak ada } \\
\text { gelembung udara }\end{array}$ & $\begin{array}{l}\text { Kebelumnya } \\
\text { khas, homogen, tidak } \\
\text { ada gelembung udara }\end{array}$ \\
\hline Minggu 3 3 Agak kental, Bening, \\
$\begin{array}{l}\text { berbau khas, } \\
\text { homogen, }\end{array}$ & $\begin{array}{l}\text { Kental, Bening, } \\
\text { berbau khas, } \\
\text { homogen. }\end{array}$ & $\begin{array}{l}\text { Kental, Bening, berbau } \\
\text { khas, homogen. }\end{array}$ \\
\hline Minggu 4 & $\begin{array}{l}\text { Agak kental, Bening, } \\
\text { berbau khas, } \\
\text { homogen. }\end{array}$ & $\begin{array}{l}\text { Kental, Bening, } \\
\text { berbau khas, } \\
\text { homogen. }\end{array}$ & $\begin{array}{l}\text { Kental, Bening, berbau } \\
\text { khas, homogen. }\end{array}$ \\
\hline
\end{tabular}

\section{Hasil evaluasi pH}

Hasil evaluasi $\mathrm{pH}$ pada masingmasing formula dapat dilihat pada grafik 1. Hasil menunjukkan $\mathrm{pH}$ berada pada kisaran 5 - 6.Pada pengamatan terhadap nilai $\mathrm{pH}$ sediaan terlihat bahwa ketiga formula cenderung berubahubah, yakni terjadi penurunan dan kenaikan $\mathrm{pH}$ secara bervariasi. Terjadi penurunan $\mathrm{pH}$ yang cukup besar pada formula 1 minggu 1 , kemudian terjadi kenaikan yang cukup besar pada formula 2 minggu 1 dan formula 3 minggu 2. Namun masing-masing formula memenuhi persyaratan $\mathrm{pH}$ kulit yaitu 4,5 - 6,5. Hal ini disebabkan karena pengaruh suhu ruangan dan pengadukan yang tidak konstan. Penurunan $\mathrm{pH}$ disebabkan masuknya $\mathrm{CO}_{2}$ kedalam wadah pada saat pengukuran dilakukan. Adanya $\mathrm{CO}_{2}$ yang bereaksi dengan air menyebabkan pH menjadi asam (Handayani, 2013).

Data $\mathrm{pH}$ yang diperoleh dari uji normalitas menunjukkan bahwa nilai sig. 0,464 > 0,05, maka $\mathrm{pH}$ terdistribusi normal. Kemudian data $\mathrm{pH}$ diuji homogenitas menunjukkan nilai sig $0,764>0,05$, maka $\mathrm{pH}$ terdistribusi homogen. Pada uji ANOVA satu arah, nilai sig $0,607>0,05$ hal ini menunjukkan bahwa tidak terdapat perbedaan yang bermakna pada $\mathrm{pH}$ masing-masing formula.

\section{Hasil Evaluasi Waktu Kering}

Hasil yang diperoleh dari pengujian waktu kering masing-masing formula dapat dilihat padagrafik 2 .

Pengujian waktu kering bertujuan untuk mengetahui berapa lama masker gel mengering pada permukaan kulit dan membentuk lapisan film. Waktu sediaan kering pada masker gel peel-off biasa digunakan adalah 15-30 menit dihitung mulai dari masker gel dioleskan hingga masker mengering. Waktu kering formula 1 berkisar antara 29 - 33 menit, sedangkan formula 2 berkisar antara 23 - 28 menit dan formula 3berkisar $22-25$ menit. Semakin banyak kadar air dalam sediaan maka waktu kering semakin meningkat (Yulin, 2015).

Data waktu kering yang diperoleh dari uji normalitas menunjukkan bahwa nilai sig. 0,119>0,05, maka waktu kering terdistribusi normal. Kemudian data waktu kering diuji homogenitas menunjukkan nilai sig 0,331>0,05, maka waktu kering terdistribusi homogen. Pada uji ANOVA satu arah, nilai sig $0,000>0,05$ hal ini menunjukkan bahwa terdapat perbedaan yang bermakna pada waktu kering masing-masingformula. 


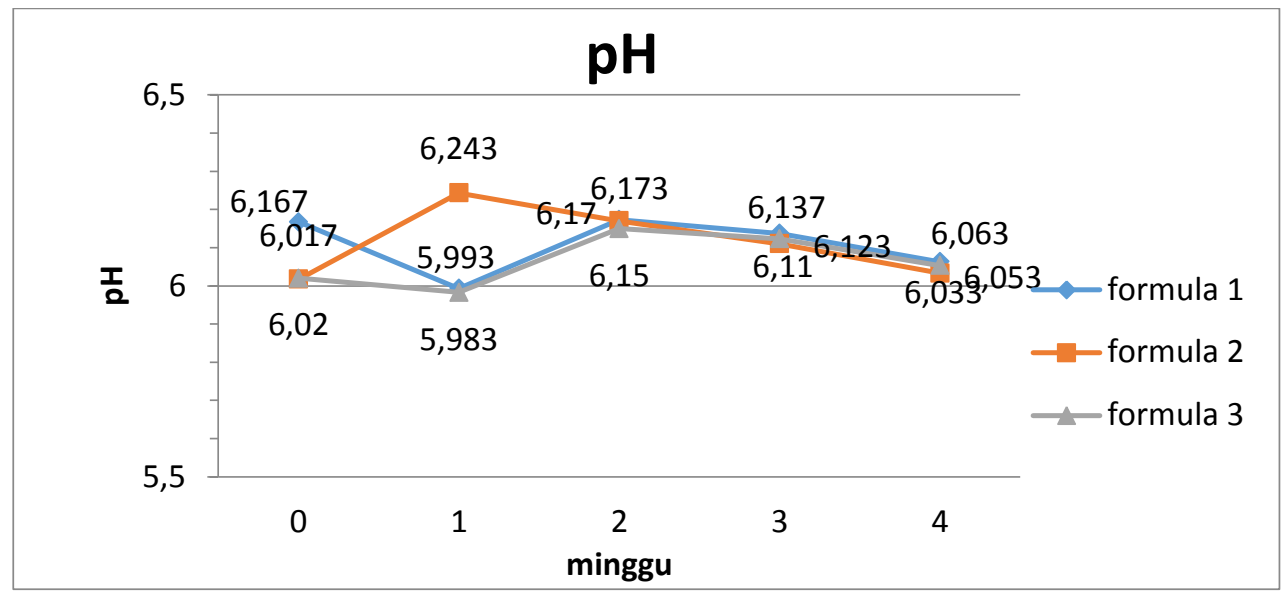

Gambar 1. Hasil evaluasi pH

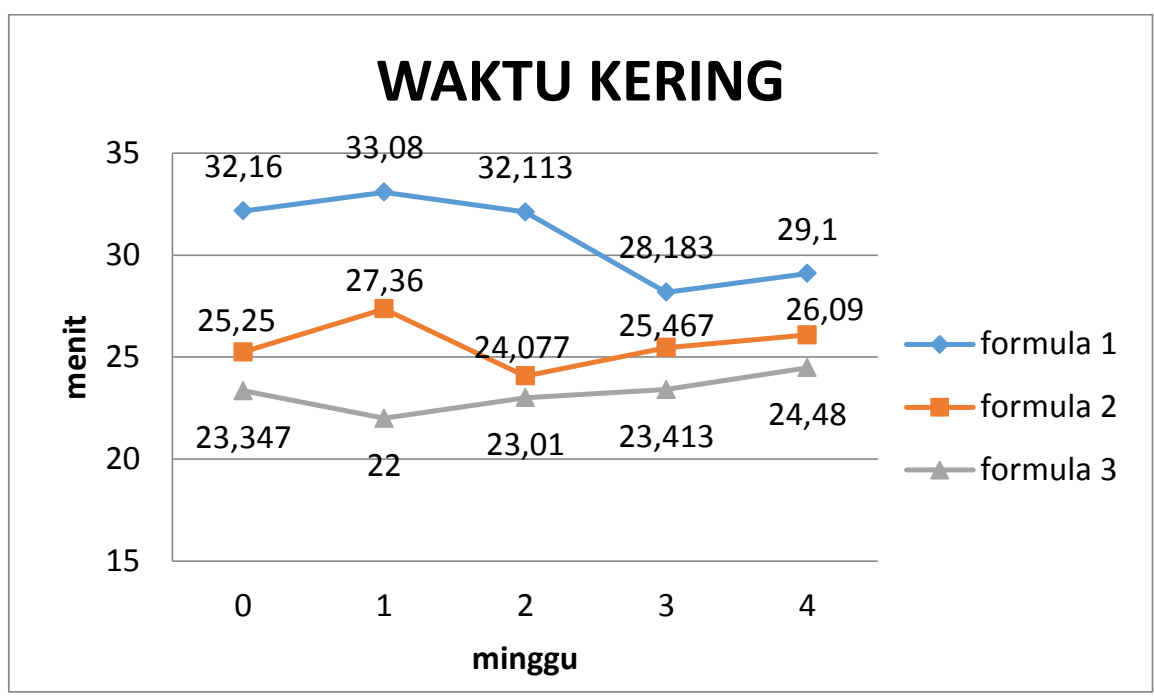

Gambar 2. Evaluasi waktu kering

\section{Hasil Evaluasi viskositas}

Hasil pengujian viskositas masker gel peel-off masing-masing formula dapat dilihat pada gambar 3 sampai 5 .

Viskositas sediaan dipengaruhi oleh beberapa faktor diantaranya adalah faktor pencampuran atau pengadukan saat proses pembuatan sediaan, penggunaan gelling agent dan konsentrasi yang digunakan. Pengukuran viskositas dilakukan dengan menggunakan Viskometer Brookfield DV-E. Hasil viskositas formula 1 terjadi penurunan pada minggu ke 1 dan minggu ke 3. Pada formula 2 dan 3 terjadi penurunan pada minggu ke 1 dan mengalami peningkatan viskositas pada minggu ke-
2, 3, dan 4. Dari hasil pemeriksaan viskositas menunjukkan bahwa semakin meningkat konsentrasi polivinil alkohol maka viskositas akan semakin meningkat dan waktu penyimpanan dapat mempengaruhi viskositas. Peningkatan viskositas disebabkan oleh gugus hidroksil yang terdapat pada polivinil alkohol belum mengalami proses hidrasi yang sempurna pada saat pembuatan (Puspita, 2014).

Data viskositas yang diperoleh dari uji normalitas menunjukkan bahwa nilai sig. $0,002<0,05$, maka viskositas tidak terdistribusi normal. Selanjutnya dilakukan uji Kruskall Wallis diperoleh nilai sig. 0,002 <0,05, maka terdapat perbedaan yang bermakna tiap formula 


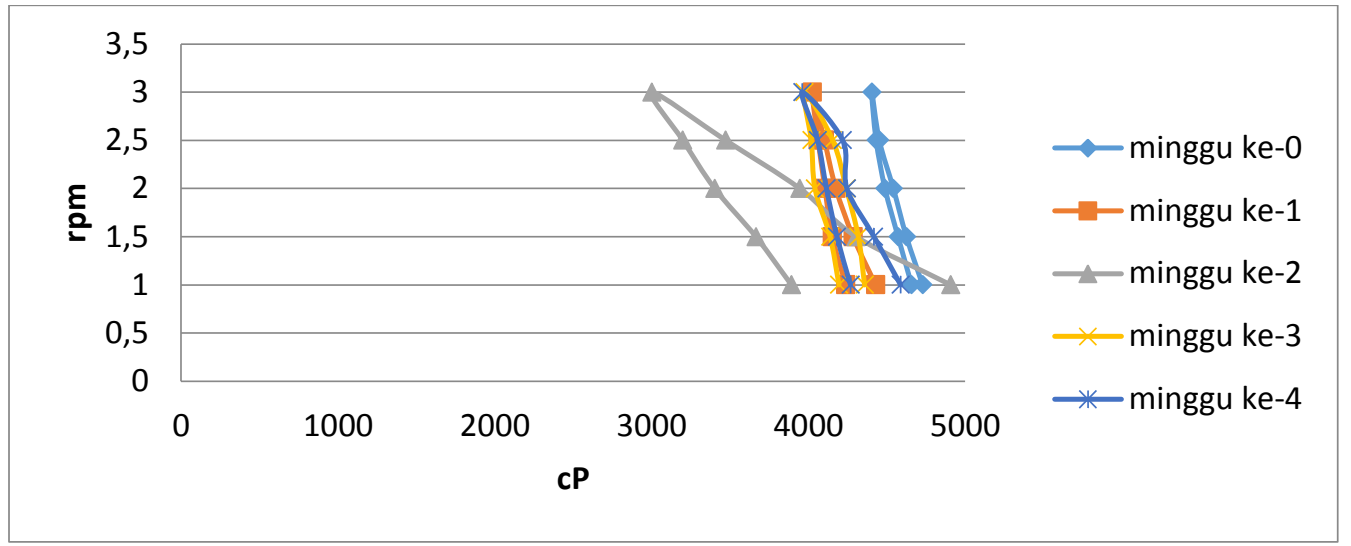

Gambar 3. Evaluasi pH Formula 1

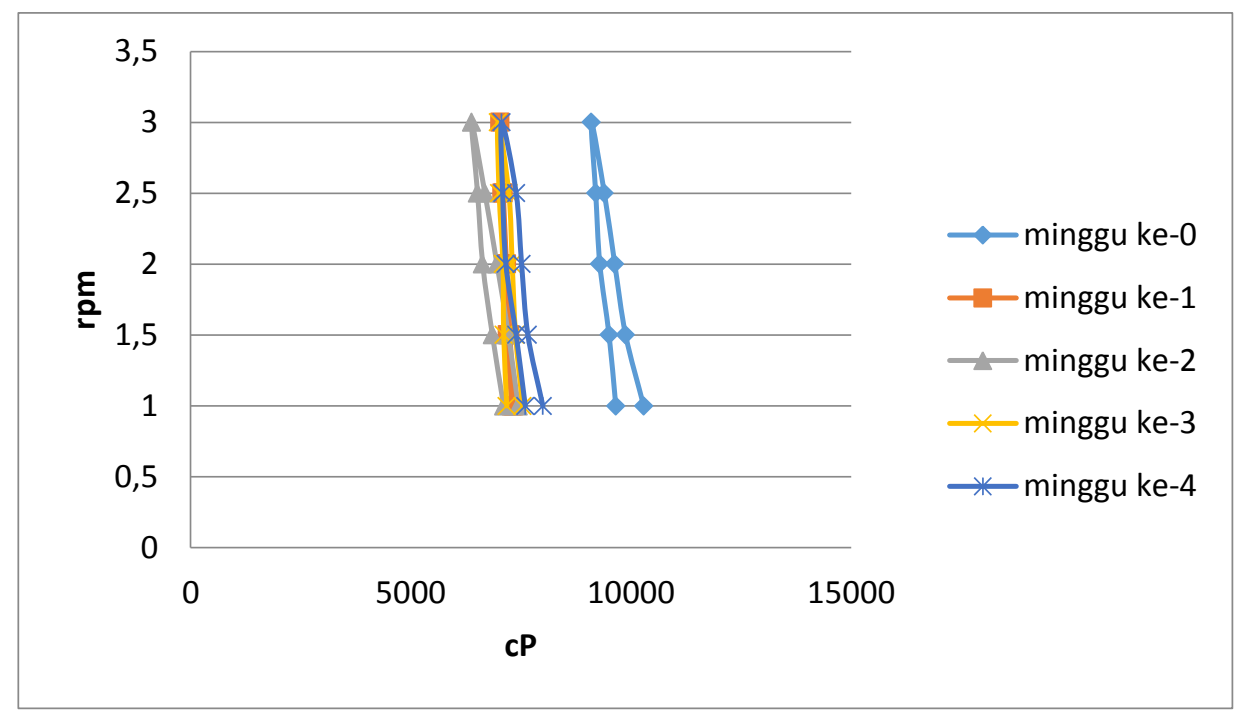

Gambar 4. Evaluasi pH Formula 2

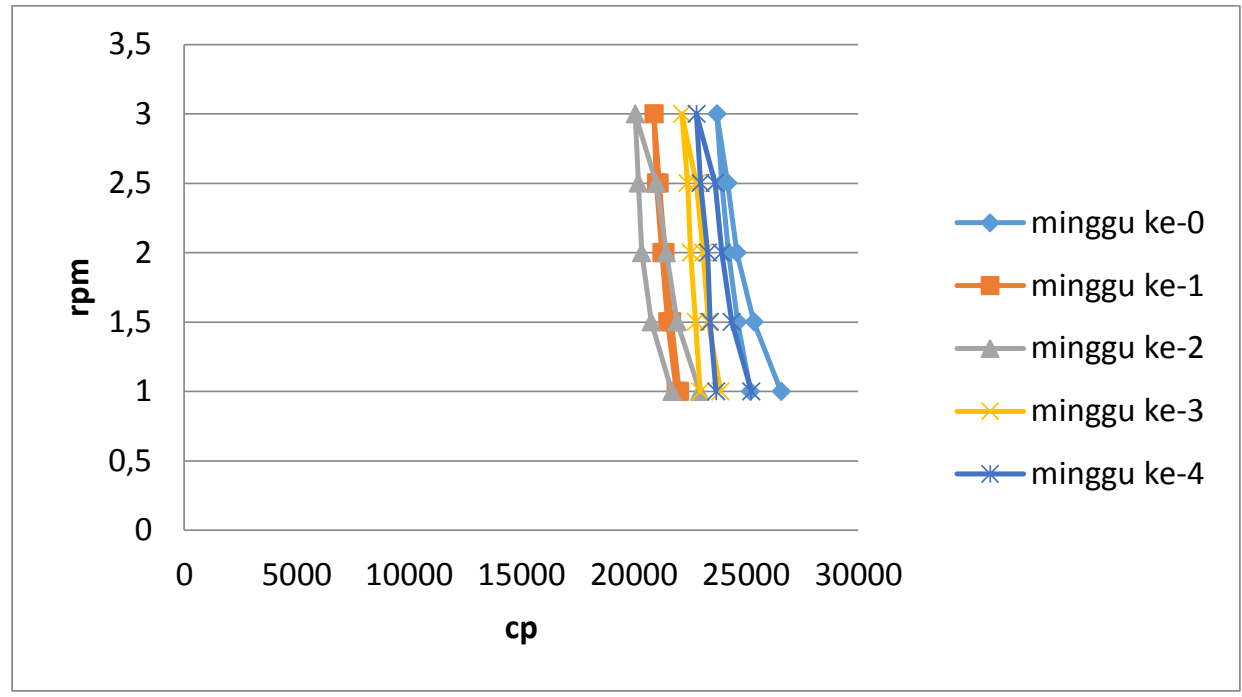

Gambar 5. Evaluasi pH Formula 3 


\section{SIMPULAN}

Berdasarkan penelitian yang telah dilakukan dapat disimpulkan bahwa peningkatan kadar gelling agent mempengaruhi viskositas dan waktu kering. Data dianalisa menunjukkan bahwa terdapat perbedaan yang bermakna pada viskositas dan waktu kering tiap formula.

\section{DAFTAR PUSTAKA}

Apgar, S. (2010). Formulasi Sabun Mandi Cair yang Mengandung Gel Daun Lidah Buaya (Aloe vera (L) Webb) dengan Basis Virgin Coconut Oil (VCO). bandung: Fakultas Matematika dan Ilmu Pengetahuan Alam Universitas Islam Bandung.

Devy, Z., Pangestuti, Y. S., Nabilla, F., Lestari, N. P., \& R., E. (2016). Formulasi dan Evaluasi Sifat Fisik Masker Gel Peel Off Lempung Bentonite. The 4 th Univesity Research Coloquium, 42-45.

Goeswin, A. (2012). Seri Farmasi Industri ke-7. Sediaan Farmasi Likuida - Semisolida. Bandung: Penerbit ITB.

Handayani, R. J. (2013). Pengaruh Peningkatan Konsentrasi Xanthan Gum sebagai Gelling Agent Terhadap Stabilitas Fisik Gel Masker Peel Off Ekstrak Etanol 96\% Buah Stroberi (Fragaria $x$ ananassa (Weston Duchesne)). Jakarta: Fakultas
Farmasi dan Sains Universitas Muhammadiyah Prof. Hamka.

Maysuhara, S. (2009). Rahasisa Canti, Sehat, dan Awet Muda (Vol. 1). Yogyakarta: Pustaka Panasea.

Minarsih, L. (2006). Penentuan

Stabilitas, Aseptibilitas dan Efektivitas Krim Pelembab Aloe Vera Linn dengan Penambahan Proilenglikol dalam Basis Vanishing Krim. Surabaya: Fakultas FarmasiUniversitas Airlangga.

Purbaya, R. (2003). Mengenal dan Memanfaatkan Khasiat Aloe Vera. Bandung: Peoner Jaya.

Puspita, A. (2014). Optimasi

Penggunaan Polivinil Alkohol

Sebagai Gelling Agent pada Masker Gel Peel Off Sari Daging Kulit Buah Semangka (Citrullus vulgaria (Thumb) Maksum dan Nakai). Jakarta: Fakultas Farmasi dan Sains Universitas Muhammadiyah Prof. Hamka.

Wasitaatmadja, S. (1997). Penuntun Ilmu Kosmetik Medik. Jakarta: UI-Press.

Yulin, H. R. (2015). Uji Stabilitas Fisik Gel Masker Peel Off Serbuk Getah Buah Pepaya (Carica papaya L.) dengan Basis Polivinil Alkohol dan Hidroksipropil Metilselulosa. Jakarta: UIN Syarif Hidayatullah. 